\title{
Economic Reasons for Declined Rice Production in Kerala, India
}

Babu Chittilappilly Varkey (Doctoral student, United Graduate School of Agricultural Sciences, Tottori University) Yoshihito Itohara (Faculty of Agriculture, Yamaguchi University)

\section{Introduction}

Occupying only $1.18 \%$ of the total geographical area, Kerala is a small state located in the southwest of India. With the high density of population, Kerala has to feed $3.10 \%$ of the total population. As against the national average of 1.57 hectare, the average size of farm holdings in Kerala is only 0.33 hectare. Over $50 \%$ of people in Kerala still subsist on the meagre income from their agricultural operations. Despite the persistent trend of declining production and productivity, the agriculture and allied sectors still account for $28.61 \%$ of the state domestic product, and $16 \%$ of the total labour force.

Contributing to $97 \%$ of the total food grains production, rice is the major food crop of Kerala. In terms of total area under cultivation (about $29 \%$ in 1975 and $11 \%$ in 2001) also, it is a principal agricultural crop. Rice farming in Kerala is also assumed having great contributions to labour absorption and environmental protection. However, the area and production of rice which were steadily increasing till the mid 1970s had to succumb to economic pressure emanating from other remunerative crops which resulted in the decline of more than 0.4 million hectare area under rice cultivation (State Planning Board, 2002). Despite considerable investment and special attention given to rice, the fact remains that the area and production under the crop continue to decline (State Planning Board, 2002). The policy and support measures in the form of group farming, introduced by the Government of Kerala in 1989, so far could not save rice farming from its continuous stagnation. There may have manifold reasons for the ineffectiveness of such support measures in revitalising the rice production. One possibility is that, farmers might have lost their interest in rice production on account of their own assessment that rice is no more an economically profitable crop. Therefore, the present study is carried out to identify the economic reasons for declined rice production, mainly from the perspective of the profitability considerations of rice farmers. The study is also aimed at evaluating the declining trend and the magnitude of deterioration of rice production in order to expose the worsening situation of rice production in Kerala state.

\section{Methodology}

Information available in a number of government publications were extensively used in the pursuit of the study objectives. The data spread over a period from 1952 to 2001 were analysed with simple aggregative tools of arithmetic mean, rate of change, compound annual growth rate, etc. Judgements based on the logical reasoning also formed the method of interpretation of data. Wherever needed, explanations to the method used are given at the end of the analytical tables.

\section{Results and Discussion}

Firstly, the extent of deterioration of rice production is assessed after splitting the total period of analysis into two phases; growth stage and declining stage (see Tables 1 and 2). A broad look at the time series data on production, area and yield of rice during the period 1952 through 2001 reveals the fact that the rice farming, which had a steady growth until 1974, is gradually reduced in size afterwards. Thus, the present trend of fast declining of production and area continues as the time passes, and if this trend is left unchecked, there may have no more rice production in the near future. It is observed that compared to the growth stage (1952-74), the declining stage (1975-01) had experienced a substantial fall in 
production (47\%) and area (63\%). The improvement in yield, which was $55 \%$ in 1974 , is also strikingly lower as 44\% in 2001.

As shown in Table 3, the compound annual growth rates computed also strongly support the above-fact finding that rice production during 1975-01 had subjected to a steady dropping, evidenced by the negative growth rates of production (-2.42\%) and area (-3.77\%). The CAGR of yield in the declining stage was also markedly lower than the growth stage. When compared to the all India growth rates also, the rice production in Kerala in general had registered poor growth rates over the period 1952-01.

The net differences in performances between the declining and growth stages are also evaluated based on the mean differences of variables as given in Table 4. The higher negative mean differences of production (-67.67), area (-39.36) and yield (-15.30) (between the declining stage and growth stage) further affirm our standpoint that

Table 1 Change in production, area and yield of rice during growth stage (1952-74)

\begin{tabular}{|c|c|c|c|c|c|c|}
\hline \multirow[b]{2}{*}{ Year } & \multicolumn{2}{|c|}{ Production } & \multicolumn{2}{|c|}{ Area } & \multicolumn{2}{|c|}{ Yield } \\
\hline & $\begin{array}{l}1000 \\
\text { tons }\end{array}$ & $\begin{array}{c}\text { change } \\
(\%)\end{array}$ & $\begin{array}{c}1000 \\
\text { ha }\end{array}$ & $\begin{array}{c}\text { change } \\
(\%)\end{array}$ & $\begin{array}{l}\text { ton/ } \\
\text { ha }\end{array}$ & $\begin{array}{c}\text { change } \\
(\%)\end{array}$ \\
\hline 1952 & 722 & .00 & 742 & .00 & .97 & .00 \\
\hline 1953 & 751 & 4.02 & 761 & 2.56 & .99 & 1.42 \\
\hline 1954 & 818 & 13.30 & 763 & 2.83 & 1.07 & 10.18 \\
\hline 1955 & 884 & 22.44 & 759 & 2.29 & 1.16 & 19.69 \\
\hline 1956 & 887 & 22.85 & 762 & 2.70 & 1.16 & 19.63 \\
\hline 1957 & 925 & 28.12 & 767 & 3.37 & 1.21 & 23.94 \\
\hline 1958 & 954 & 32.13 & 768 & 3.50 & 1.24 & 27.66 \\
\hline 1959 & 1038 & 43.77 & 769 & 3.64 & 1.35 & 38.72 \\
\hline 1960 & 1066 & 47.65 & 779 & 4.99 & 1.37 & 40.63 \\
\hline 1961 & 1004 & 39.06 & 753 & 1.48 & 1.33 & 37.03 \\
\hline 1962 & 1093 & 51.39 & 803 & 8.22 & 1.36 & 39.88 \\
\hline 1963 & 1128 & 56.23 & 805 & 8.49 & 1.40 & 44.01 \\
\hline 1964 & 1121 & 55.26 & 801 & 7.95 & 1.40 & 43.83 \\
\hline 1965 & 997 & 38.09 & 802 & 8.09 & 1.24 & 27.76 \\
\hline 1966 & 1084 & 50.14 & 799 & 7.68 & 1.36 & 39.43 \\
\hline 1967 & 1124 & 55.68 & 810 & 9.16 & 1.39 & 42.61 \\
\hline 1968 & 1231 & 70.50 & 874 & 17.79 & 1.41 & 44.75 \\
\hline 1969 & 1251 & 73.27 & 874 & 17.79 & 1.43 & 47.10 \\
\hline 1970 & 1298 & 79.78 & 875 & 17.92 & 1.48 & 52.45 \\
\hline 1971 & 1352 & 87.26 & 875 & 17.92 & 1.55 & 58.79 \\
\hline 1972 & 1376 & 90.58 & 877 & 18.19 & 1.57 & 61.24 \\
\hline 1973 & 1257 & 74.10 & 875 & 17.92 & 1.44 & 47.64 \\
\hline 1974 & 1334 & 84.76 & 882 & 18.87 & 1.51 & 55.44 \\
\hline
\end{tabular}

Source: Statistics for Planning (State Planning Board, 1952-1974) Note: 'Rate of change (in \%)' is obtained by, (current year data $\div$ base year data $\times 100)-100$. Base year $=1952$. rice production in Kerala is on tremendous decline since 1975, which may be a setback to the attainment of the goals of food security, labour absorption and environmental protection. The revelations of this part of the study are also in conformity with the conclusion of a previous

Table 2 Change in production, area and yield of rice during declining stage (1975-01)

\begin{tabular}{l|r|r|r|r|r|r}
\hline \multirow{2}{*}{ Year } & \multicolumn{2}{|c|}{ Production } & \multicolumn{2}{c|}{ Area } & \multicolumn{2}{c}{ Yield } \\
\cline { 2 - 7 } & $\begin{array}{r}1000 \\
\text { tons }\end{array}$ & $\begin{array}{c}\text { change } \\
(\%)\end{array}$ & $\begin{array}{c}1000 \\
\text { ha }\end{array}$ & $\begin{array}{c}\text { change } \\
(\%)\end{array}$ & $\begin{array}{c}\text { ton/ } \\
\text { ha }\end{array}$ & $\begin{array}{c}\text { change } \\
(\%)\end{array}$ \\
\hline 1975 & 1329 & .00 & 876 & .00 & 1.52 & .00 \\
1976 & 1254 & -5.64 & 854 & -2.51 & 1.47 & -3.21 \\
1977 & 1295 & -2.56 & 840 & -4.11 & 1.54 & 1.62 \\
1978 & 1273 & -4.21 & 799 & -8.79 & 1.59 & 5.02 \\
1979 & 1300 & -2.18 & 793 & -9.47 & 1.64 & 8.06 \\
1980 & 1272 & -4.29 & 802 & -8.45 & 1.59 & 4.54 \\
1981 & 1339 & 0.75 & 807 & -7.88 & 1.66 & 9.37 \\
1982 & 1306 & -1.73 & 778 & -11.19 & 1.68 & 10.65 \\
1983 & 1208 & -9.10 & 740 & -15.53 & 1.63 & 7.60 \\
1984 & 1256 & -5.49 & 730 & -16.67 & 1.72 & 13.41 \\
1985 & 1173 & -11.74 & 678 & -22.60 & 1.73 & 14.04 \\
1986 & 1134 & -14.67 & 664 & -24.20 & 1.71 & 12.57 \\
1987 & 1033 & -22.27 & 604 & -31.05 & 1.71 & 12.73 \\
1988 & 1013 & -23.78 & 578 & -34.02 & 1.75 & 15.52 \\
1989 & 1141 & -14.15 & 583 & -33.45 & 1.96 & 29.00 \\
1990 & 1087 & -18.21 & 559 & -36.19 & 1.94 & 28.17 \\
1991 & 1060 & -20.24 & 541 & -38.24 & 1.96 & 29.15 \\
1992 & 1085 & -18.36 & 537 & -38.70 & 2.02 & 33.18 \\
1993 & 1004 & -24.45 & 508 & -42.01 & 1.98 & 30.27 \\
1994 & 975 & -26.64 & 503 & -42.58 & 1.94 & 27.77 \\
1995 & 953 & -28.29 & 471 & -46.23 & 2.02 & 33.37 \\
1996 & 871 & -34.46 & 431 & -50.80 & 2.02 & 33.21 \\
1997 & 765 & -42.44 & 387 & -55.82 & 1.98 & 30.30 \\
1998 & 727 & -45.30 & 353 & -59.70 & 2.06 & 35.75 \\
1999 & 771 & -41.99 & 350 & -60.05 & 2.20 & 45.20 \\
2000 & 751 & -43.49 & 347 & -60.39 & 2.16 & 42.66 \\
2001 & 704 & -47.03 & 322 & -63.24 & 2.19 & 44.11 \\
\hline
\end{tabular}

Source: Statistics for Planning (State Planning Board, 1975-2001) Note: 'Rate of change (in \%)' is obtained by, (current year data $\div$ base year data $\times 100)-100$. Base year $=1975$.

Table 3 Compound annual growth rates (CAGR) of production, area and yield of rice (1952-01)

\begin{tabular}{l|r|r|r}
\hline \multicolumn{4}{c}{ Kerala State } \\
\hline \multicolumn{1}{c}{ Farming Period } & Production & Area & Yield \\
\hline Growth Stage (1952-74) & 2.83 & 0.79 & 2.03 \\
Declining Stage (1975-01) & -2.42 & -3.77 & 1.41 \\
Total Period (1952-01) & -0.05 & -1.69 & 1.66 \\
\hline \multicolumn{4}{c}{ All India } \\
Total Period (1952-01) & 2.85 & 0.78 & 2.05 \\
\hline Note: CAGR $=$ (end year value $\div$ starting year value) ${ }^{1 / \pi}-1$, \\
where $\mathrm{n}=$ number of intervals between the end and start- \\
ing years
\end{tabular}


study that governmental interventions in the form of group farming which consumed 460 million rupees of investment could not salvage rice production from its prevalent problems (Government of Kerala, 1997). In the remaining portion of the study, we would like to clarify whether there had some economic reasons, chiefly rice farmers' own economic considerations and profit motives that might have resulted in the loss of their interest in rice farming.

In our efforts to comprehend the economic reasons, firstly, an inter-state comparison of yield, production cost, farm harvest price and net return (profit) of rice production during 19812001 is attempted. As Table 5 shows, among the major rice producing states, only Punjab is seemed to be having a comparatively good performance in terms of yield, cost and profit. The rice production in Kerala is found to be very deplorable in terms of its yield (1913 kg/ha, the lowest) and cost of production (Rs.5.27/ kg, the highest). Despite this unpleasant situation, its per hectare profit is slightly better than Andhra Pradesh (the poor most state in terms of net return), because of the highest unit harvest price (Rs.5.76/kg). However, with a meagre profit of Rs.914 from a hectare area of cultivation, rice production cannot be considered as economically sustainable. It is not simply a matter of making some profit, but sufficiency of the profit is the main criterion for the sustenance of any economic activity. This sufficiency consideration is derived from the expected minimum return from the given resources utilised, and from a comparison with return from alternative uses, and the need for money to run the farm, family etc.

In this context, it is very imperative to answer the question "what should be the minimum required net profit from rice production"? A rough estimate based on the norm, "the expected minimum return' for a full-time rice farm household in Kerala for the year 1997 is attempted. In doing so, the standard measures used here are the poverty line, the salary of a last grade servant in government and the interest on total cost
Table 4 Mean differences of variables between declining stage and growth stage (1952-01)

\begin{tabular}{c|r|r|r}
\hline Variables & \multicolumn{1}{c|}{ N } & \multicolumn{1}{c}{ Mean } & Mean Difference \\
\hline Production & & & \\
DS (1975-01) & 27 & -18.961 & -67.673 \\
GS (1952-74) & 23 & 48.711 & \\
Area & & & \\
DS (1975-01) & 27 & -30.513 & -39.355 \\
GS (1952-74) & 23 & 8.842 & \\
Yield & & & \\
DS (1975-01) & 27 & 20.520 & -15.298 \\
GS (1952-74) & 23 & 35.818 & \\
Note: 1. DS = Declining stage, GS = Growth stage \\
2. The 'rate of change' figures shown in Table 1 and 2 are \\
used to compute the mean values of variables.
\end{tabular}

Table 5 Yield, cost, price and net return of rice in Kerala and other states in India (1981-01)

\begin{tabular}{|c|c|c|c|c|c|c|}
\hline \multirow[t]{2}{*}{ State } & \multirow{2}{*}{$\begin{array}{c}\text { Yield } \\
(\mathrm{kg} / \mathrm{ha})\end{array}$} & \multicolumn{2}{|c|}{$\begin{array}{c}\text { Production } \\
\text { Cost }\end{array}$} & \multicolumn{2}{|c|}{$\begin{array}{c}\text { Farm Harvest } \\
\text { Price }\end{array}$} & \multirow{2}{*}{$\begin{array}{c}\text { Net } \\
\text { Return } \\
\text { (Rs./ha) }\end{array}$} \\
\hline & & Rs./kg & Rs./ha & Rs./kg & Rs./ha & \\
\hline \multicolumn{7}{|l|}{$\underline{\text { Kerala }}$} \\
\hline 1981 & 1660 & 2.11 & 3503 & 2.27 & 3768 & 265 \\
\hline 1985 & 1729 & 3.35 & 5792 & 3.60 & 6224 & 432 \\
\hline 1989 & 1956 & 4.22 & 8254 & 4.48 & 8763 & 509 \\
\hline 1993 & 1977 & 5.03 & 9944 & 6.19 & 12238 & 2294 \\
\hline 1997 & 1975 & 6.40 & 12640 & 8.31 & 16412 & 3772 \\
\hline 2001 & 2182 & 10.52 & 22955 & 9.70 & 21165 & -1790 \\
\hline Average & 1913 & 5.27 & 10515 & 5.76 & 11428 & 914 \\
\hline \multicolumn{7}{|c|}{ Andhra Pradesh } \\
\hline 1981 & 2058 & 1.67 & 3437 & 1.87 & 3848 & 411 \\
\hline 1985 & 2205 & 2.09 & 4608 & 2.27 & 5005 & 397 \\
\hline 1989 & 2367 & 2.66 & 6296 & 2.96 & 7006 & 710 \\
\hline 1993 & 2696 & 5.10 & 13750 & 5.67 & 15286 & 1536 \\
\hline 1997 & 2431 & 6.06 & 14732 & 6.64 & 16142 & 1410 \\
\hline 2001 & 2978 & 7.40 & 22037 & 7.61 & 22662 & 625 \\
\hline Average & 2456 & 4.16 & 10810 & 4.50 & 11658 & 848 \\
\hline \multicolumn{7}{|l|}{ West Bengal } \\
\hline 1981 & 1447 & 1.82 & 2634 & 2.04 & 2952 & 318 \\
\hline 1985 & 1581 & 1.88 & 2972 & 2.39 & 3779 & 807 \\
\hline 1989 & 1956 & 2.72 & 5320 & 3.13 & 6122 & 802 \\
\hline 1993 & 2070 & 4.70 & 9729 & 5.64 & 11675 & 1946 \\
\hline 1997 & 2243 & 5.67 & 12718 & 7.37 & 16531 & 3813 \\
\hline 2001 & 2514 & 7.00 & 17598 & 7.45 & 18729 & 1131 \\
\hline Average & 1969 & 3.97 & 8495 & 4.67 & 9965 & 1470 \\
\hline \multicolumn{7}{|l|}{ Punjab } \\
\hline 1981 & 2975 & 1.52 & 4522 & 1.84 & 5474 & 952 \\
\hline 1985 & 3196 & 1.88 & 6008 & 2.19 & 6999 & 991 \\
\hline 1989 & 3243 & 2.19 & 7102 & 2.72 & 8821 & 1719 \\
\hline 1993 & 3524 & 3.99 & 14061 & 5.22 & 18395 & 4334 \\
\hline 1997 & 3465 & 5.15 & 17845 & 6.66 & 23077 & 5232 \\
\hline 2001 & 3545 & 6.10 & 21625 & 7.61 & 26977 & 5352 \\
\hline Average & 3325 & 3.47 & 11860 & 4.37 & 14957 & 3097 \\
\hline
\end{tabular}

Source: Complied from various Government publications

for rice production. Since the family income of people below the poverty line is Rs.18000 and the 
average size of farm holdings is 0.33 hectare, the minimum net income from a hectare should be Rs.54546. If a farmer is eligible for an income equivalent of a last grade employee of state government with a basic pay of Rs.2610, Dearness Allowance of $20 \%$ and House Rent Allowance of Rs.60 per month, one hectare of rice farm should earn an annual net income of Rs.38304. With the total cost of Rs.110000 per hectare (operational cost Rs.15000 and fixed cost of Rs.95000), a farmer can expect Rs.13200 per year (with 12\% rate of interest) if the same amount was invested in a bank without any effort. However, even if we calculate the total profit from rice production with the annual cropping intensity of $179 \%$, it would amount to only Rs.6752 (see the net return figure for Kerala for the year 1997 in Table 5), which is about two-fold lower than the interest income from bank deposit. This situation proves the fact that the net return from rice production is not enough to compensate even for the least opportunity cost (interest income). Therefore, from these illustrations, it can be safely inferred that the rice production in Kerala is not economically sustainable as the negligible profit from it is found inadequate for a predominantly rice producing household by any standard.

Although, it is convincingly verified from the foregoing section of analysis that the low profitability is the major reason for the retreat of rice production, an inter-crop comparison is also made to examine whether the existence of more remu- nerative crops had also been equally responsible for its pulling out. As demonstrated in Table 6, the major crops drastically shrank in terms of production and area were rice, tapioca and cashew nut. Though we do not have data as to which crop is replaced by which crop, the major shift might have been taken place in favour of rubber, banana and pepper, as the growth rates for these crops are relatively higher. The cropwise data as percentage to total cropped area in Table 7 also confirms the structural transformation took place in the agricultural crop sector. The extremely high-level loss of rice fields (18.61\%) was because of the large-scale conversion for agricultural and non-agricultural uses, digging for tile soil and keeping the land as fallow (uncultivated).

A review of the available studies on the conversion of rice fields reveals the fact that rice farmers have largely shifted to rubber, coconut, banana and other cash crops. (see Fig.1). From the field level interactions of the first author with the rice farmers, it is observed that most of the rice fields in Kerala have alternative agricultural uses owing to the diversified soil, climatic and topographic conditions, and their location all over Kerala under eight agroclimatic zones. Over the years, Kerala farmers are fond of growing commercial or cash crops rather than food crops, and they carry on expanding the farming area under these high-income crops whereby reducing the size of uneconomical rice fields. However, the

Table 6 Growth in production, area, yield and price of principal crops in Kerala (1975-01)

\begin{tabular}{l|r|r|r|r|r|r|r|r|r|r|r|r}
\hline \multirow{2}{*}{$\begin{array}{c}\text { Principal } \\
\text { Crops }\end{array}$} & \multicolumn{2}{|c|}{ Production (Tonnes) } & \multicolumn{3}{c|}{ Area (hectare) } & \multicolumn{2}{c|}{ Yield (kg/ha) } & \multicolumn{2}{c}{ Farm Price (Rs./Qtl) } \\
\cline { 2 - 12 } & \multicolumn{1}{c|}{1975} & 2001 & $\begin{array}{c}\text { Growth } \\
\text { (in \%) }\end{array}$ & 1975 & 2001 & $\begin{array}{c}\text { Growth } \\
\text { (in \%) }\end{array}$ & 1975 & 2001 & $\begin{array}{c}\text { Growth } \\
\text { (in \%) }\end{array}$ & 1975 & 2001 & $\begin{array}{l}\text { Growth } \\
\text { (in \%) }\end{array}$ \\
\hline Rice & 1329403 & 703504 & -47.08 & 876000 & 322368 & -63.20 & 1518 & 2182 & 43.74 & 121 & 586 & 384.30 \\
Tapioca & 5390217 & 2455880 & -54.44 & 326900 & 111189 & -65.99 & 16489 & 22087 & 33.95 & 29 & 320 & 1003.45 \\
Pepper & 24580 & 58240 & 136.94 & 108300 & 203956 & 188.33 & 227 & 286 & 25.99 & 913 & 6942 & 660.35 \\
Cashew nut & 81900 & 65867 & -19.58 & 141300 & 89718 & -36.51 & 580 & 734 & 26.55 & 436 & 2520 & 477.98 \\
Banana & 317405 & 769085 & 142.30 & 49300 & 106054 & 115.12 & 6438 & 7252 & 12.64 & 161 & 1001 & 521.74 \\
Coconut** & 3439 & 5479 & 59.32 & 692900 & 905718 & 30.71 & 4963 & 6049 & 21.88 & 84 & 341 & 305.95 \\
Rubber & 128769 & 580350 & 350.69 & 206700 & 475039 & 129.82 & 623 & 1222 & 96.15 & 610 & 3228 & 429.18 \\
Arecanut** & 56935 & 84861 & 49.05 & 76600 & 93193 & 21.66 & 743 & 911 & 22.61 & 6 & 33 & 450.00 \\
\hline
\end{tabular}

Source: Compiled from various Government Publications

Note: ** production is in million nuts, yield in nuts per hectare and farm price in rupees per 100 nuts 
rice fields that are neither fit for more remunerative crops nor good for non-agricultural purposes owing to the very nature of land conditions are mostly left as fallow.

The issue of alternative profitability, a major decisive factor in production decisions, is also examined with the help of the information furnished in Table 8. The figures on per hectare gross return, derived from the yield and farm harvest price (sales value) data, clearly exemplify the fact that rice has the lowest gross return among the major crops cultivated in Kerala. In this respect, in the 'project report on group farming in Kerala' (Suresh, 2000), it was suggested that the net return would be trivial or even negative in the case of paddy (rice) whereas in the case of the crops with lesser labour and other inputs, net return would also be attractive. Nevertheless, the very inclination trend towards other crops (see Fig.1) itself is a sensible confirmation for the profit responsiveness of rice farmers. A study on 'food grain production on the decline' (Nair, 2002) had also claimed that rice and tapioca farmers who have shifted to rubber, coconut and other cash crops were essentially motivated by the more remunerative price of these crops. In our viewpoint, rice farmers might have thought that it would be economical to buy rice imported from other states in the open market with the high income they earn from the commercial crops.
Table 7 Area of principal crops in Kerala Proportion and change (1975-01)

\begin{tabular}{l|r|r|r}
\hline \multicolumn{1}{c|}{ Principal Crops } & \multicolumn{1}{|c|}{1975} & \multicolumn{1}{c|}{2001} & Change \\
\hline Rice & 29.38 & 10.77 & -18.61 \\
Tapioca & 10.97 & 3.71 & -7.26 \\
Pepper & 3.63 & 6.82 & 3.19 \\
Cashew nut & 4.74 & 3.00 & -1.74 \\
Banana & 1.65 & 3.54 & 1.89 \\
Coconut & 23.24 & 30.27 & 7.03 \\
Rubber & 6.93 & 15.88 & 8.95 \\
Arecanut & 2.57 & 3.12 & 0.55 \\
Other crops & 16.89 & 22.89 & 6.00 \\
Total cropped & 2981300 & 2992252 & 10952 \\
area (In ha) & $(100)$ & $(100)$ & \\
\hline Sour Comp)
\end{tabular}

Source: Compiled from various Government of Kerala Publications

Table 8 Gross Return from rice and other crops in Kerala

\begin{tabular}{l|r|r|r}
\multicolumn{1}{c|}{ Crops } & \multicolumn{1}{c|}{$\begin{array}{c}\text { Yield } \\
\text { (kg/ha) }\end{array}$} & $\begin{array}{c}\text { Farm Harvest } \\
\text { Price (Rs.) }\end{array}$ & $\begin{array}{c}\text { Gross Return } \\
\text { (Rs./ha) }\end{array}$ \\
\hline Rice & 2090 & $906 /$ Qtl & 18935 \\
Tapioca & 22506 & $315 /$ Qtl & 70894 \\
Pepper & 303 & $13203 /$ Qtl & 40005 \\
Cashew nut & 694 & $2902 /$ Qtl & 20140 \\
Banana & 8833 & $911 /$ Qtl & 80469 \\
Coconut** & 5909 & $401 / 100$ & 23695 \\
Rubber & 1173 & $3720 /$ Qtl & 43636 \\
Arecanut** & 211792 & $49 / 100$ & 103778 \\
\hline
\end{tabular}

Source: Compiled from various Government of Kerala Publications Note: ** Yield is in nuts per hectare

Thus, our findings and observations emerged from the inter-state and inter-crop comparisons of rice production clearly confirm the fact that low profit on one side, and attractive alternative crops on the other side have driven out the farmers from rice cultivation.

\begin{tabular}{|c|c|c|c|}
\hline ST: & $\begin{array}{l}\text { Stutiv Gromp } \\
\text { or Researcher: }\end{array}$ & Extent and nethod of conversion/loss of rice fields & Direction of conversion \\
\hline 1 & Jeemol (1981) & - Conversion is with or without filling the rice fields & Mainly in favour of coconut (1961-79) \\
\hline 2 & Sarina John (1997) & , & In favour of teak and rubber plantation \\
\hline 3 & $\begin{array}{l}\text { Popular Expert } \\
\text { Committee (1998) } \\
\text { [Study period: } \\
\text { 1976-1996] }\end{array}$ & $\begin{array}{l}\text { - The rate of loss per year: } 21,000 \text { ha }(60 \mathrm{ha} / \text { day }) \\
\text { - Conversion by filling the rice fields: } 327,000 \text { ha } \\
\text { - loss by digging the rice fields: } 28,000 \text { ha } \\
\text { - loss by keeping as fallow without cultivation: } 47,000 \text { ha } \\
\text { - Total area lost by conversion or other: } 402,000 \text { ha }\end{array}$ & $\begin{array}{l}\text { Tree crops (coconut, rubber etc): } 18.5 \% \\
\text { Annual crops (banana, vegetables): } 7.5 \% \\
\text { Non-agricultural (mainly housing): } 11.4 \% \\
\text { Digging out for soil to make tiles: } 5.4 \% \\
\text { Fallow (uncultivated): } 5.4 \%\end{array}$ \\
\hline 4 & Latha (2001) & - Conversion is with or without filling the rice fields & $\begin{array}{l}\text { Coconut, arecanut and rubber since } 1960 \\
\text { Banana on commercial scale since } 1980\end{array}$ \\
\hline
\end{tabular}

Source: 1. Compiled from ICAR Project Report, Kerala (Suresh, 2000)

2. Centre for the Development Studies KRPLLD Project Report, Kerala (Latha, 2001)

3. Study Report (Popular Expert Committee, 1988)

Figure 1 Previous study results on the extent, method and direction of conversion of rice fields in Kerala 


\section{Conclusion}

Rice farming in Kerala has almost reached on its end-phase of total disappearance. The reality is that rice farmers do not recognise rice as an economically sustainable crop. Higher cost, poor yield, lower profit, and the existence of opportunities that are more rewarding, etc., are the major economic reasons for the declined rice production. Comparatively poor profits from rice and the easiness of shifting rice fields to crops that are more profitable have certainly induced rice farmers to turn in favour of other crops. Meanwhile, it is very alarming to note that some farmers have even sold their lands or simply possessed it without any activity. The shrinking of area and production of rice is thus, largely attributable to its declining profitability.

Even though there had policy and institutional supports in the form of group farming, there are no symptoms of recovery even in the recent years as the governmental support measures so far could not demonstrate rice farming as a remunerative and equally rewarding crop. Hence, efforts have to be made to formulate more vibrant schemes to keep rice production on profitable line. This in turn calls for the attention of policy makers, researchers and extension staff.

\section{References}

[1] Government of Kerala, 1997. Report of the Task Force on Land Reforms and Agrarian Institutions, Trivandrum.

[2] Latha, 2001. An Analysis of the Sustainability of Commercial Banana Production in Watershed based Agricultural Development, KRPLLD Project, Centre for the Development Studies, Kerala [Online] http://www.geocities.com/klri98/latha.htm

[3] Nair, G.K., 2002. Foodgrain production on the decline, Financial Daily, The Hindu, Kochi [Online] http://www.blonnet.com/ 2002/05/06/stories/2002050601981300.htm

[4] Popular Expert Committee, 1998. Study Report Summary, Paddy Field Protection Movement, Kerala

[5] State Planning Board, 1952-2001. Statistics for Planning, Government of Kerala, Trivandrum.

[6] State Planning Board, 2002. Draft - Tenth Five Year Plan and Annual Plan 2002, Government of Kerala, Trivandrum.

[7] State Planning Board, 2002. Economic Review, Government of Kerala, Trivandrum.

[8] Suresh, K. A., 2000. Group Management Approach to Agricultural Development - A Case Study of Rice Farming in Kerala, Indian Council of Agricultural Research (ICAR) Project Report, Kerala. 